\title{
An Investigation on Preference Factors in Recreation Area Usage of Sport Science Students
}

\author{
Osman Tolga Togo (Corresponding author) \\ School of Physical Education and Sports, Harran University, Şanlıurfa, Turkey \\ Tel: 90-533-364-4709 E-mail: tolgatogo@gmail.com
}

Arda Öztürk

Faculty of Sport Science, Pamukkale University, Denizli, Turkey

Tel: 90-532-786-4874 E-mail: ardaozturk82@hotmail.com

Received: March 23, 2020 Accepted: May 2, 2020 Published: May 11, 2020

doi:10.5296/jei.v6i1.16743 URL: https://doi.org/10.5296/jei.v6i1.16743

\begin{abstract}
In this study, it is aimed to determine the factors of preference of the recreational areas made by the municipalities of the students studying in the sports departments of the university and living in different geographical regions. The working group of universities in two regions in Turkey are 127 girls and boys studying sports science 182 's of a total of 309 students. As a data collection tool, Recreation Area Preference Scale (RATE) developed by Gümüş and Alay Özgül (2017) was used. RATE consists of 24 sub-dimensions and 5 sub-dimensions: sport diversity, personnel, location, physical facilities and activity. The findings show that the data do not have normal distribution. Mann Whitney-U test was used for paired comparisons and Kruskall Wallis Analysis test was used for three and more comparisons. Significant differences were found in all sub-dimensions of the gender variable according to the variables of residence, special vehicle, age, marital status and department $(\mathrm{P}<0.05)$.
\end{abstract}

Keywords: Recreation area, Sports science students, Preference factors

\section{Introduction}

Recreation is defined as the activities that people intentionally perform with their free will in their free time after fulfilling their vital needs. One of the most commonly used description of recreation is that it covers activities conducted with an intention to relax after tiredness. These activities make an individual relaxed, refreshed and prepared for work. It is often considered to be for entertainment purposes only and no specific meaning is attributed to it. Pleasure, 
happiness and willingness are the main goals in free times while experiences are the means (Voight, 1998).

Recreation is overall physical and intellectual activities that are conducted through the self-control of an individual in times of leisure, and aim to revive the physical and intellectual state of the individual in accordance with the structure of the society in which the individual was born and the cultural and economic conditions that the individual lives in (Boman et al., 2013).

Recreation includes intentionally selected activities performed by individuals with the aim of enjoying themselves and also in order to regain, protect or maintain their physical and mental health which are threatened or adversely affected by intensive work load, routine lifestyle or negative environmental effects (Gurbuz, 2014). These activities which provide satisfaction for individuals can be voluntarily and electively conducted within a group or individually in a complete free time other than the time spent for working and vital needs (Karaküçük, 1995).

While spending free time effectively contributes to strengthening social adaptation, it is especially suggested that it can protect the young population from harmful habits (Tuncay, 2000). Today, a large population living in cities allocates a certain portion of their income for recreational sports activities, which is a result of an awareness about health. Government and local authorities should also support these activities and encourage their citizens. Among the local establishments, municipalities are regarded as the most important one having the closest relationship with the public. This is due to the fact that most of the municipalities' duties are closely related to the daily life of people (Ağılönü, 2009).

It is necessary for individuals to evaluate their free time consciously so that they can be healthy, know themselves, be aware of their talents, competencies and limits and realize their potential completely (Yetim, 2011).

This time frame, which you can use freely for participation in recreational activities, should be the time reserved for working and compulsory needs (Karaküçük, 2005). Apart from these compulsory studies, individuals tend to different areas in order to feel good and renew themselves in terms of psychological, physiological and social aspects. When we look at people in industrialized societies fast their inactive and monotonous lives in their life, their psychological and can be affect physiologically negatively and cause major health problems (Demirel \& Harmandar, 2009).

Based on the principle of protecting public health, which is one of the primary duties of the state, local governments have started to build modern and multi-functional recreation areas with the encouragement of governments (Gümüş, 2017). With the present study, it is aimed to make a contribution to the planning process of new recreation areas by searching for answers to the question of how people can benefit from the recreation areas that are being constructed increasingly because of increasing demands.

This study was carried out to investigate the preference factors of university students at sports sciences department for the use of recreation areas and identify the differences and similarities in recreation barriers of the university students in different regions. 


\section{Macrothink}

\section{Method}

\subsection{Aim of the Study}

This study aimed to investigate the preference factors of university students studying in sports sciences departments and living in different geographical areas for the use of recreational areas built by municipalities.

\subsection{Participants of the Study}

The study was designed according to a descriptive design model and the data of the study was collected through questionnaire. The study was research designed according to haphazardly sample method. The population of the study was comprised of students studying in sports sciences departments in Turkey and the sample consisted of a total of 309 students consisting of 127 girls and 182 boys studying sports sciences at some universities of Turkey.

\subsection{Data Collection Tools}

In this study, the scale of Preference Factors in Recreation Area (PFRA) developed by Gümüş and Alay Özgül (2017) was used. PFRA consists of 24 items and five subscales including sports variety, personnel, location, physical environment/facilities and activity. PFRA is a 5-point scale (1: Not at all important, 2: Not important, 3: Neutral, 4: Important, 5: Very Important). PFRA was developed by making use of previous studies in this field. While PFRA scale was being developed, the factors that could affect individuals while choosing their recreation areas were taken into consideration, and the studies in the literature were utilized accordingly. The studies that were benefitted from during the development of the scale were those of Wilcox, Castro, King, Housemann, and Brownson (2000), and Pelletier Fortier, Vallerand, Briere, Tuson, and Blais (1995) in "Sports Variety" sub-scale (3 items); Öcal (2012), and Stanis, Schneider, Chavez and Shinew (2009) in "Personnel" subscale (2 items); Uzun and Müderrisoğlu (2010) in "Location" subscale (2 items); Uzun and Müderrisoğlu (2010), and Öcal (2012) in "Physical Environment/Facilities" subscale (4 items); and finally Tütüncü, Aydın, Küçükusta, Avc1, and Taş (2011), Uzun and Müderrisoğlu (2010), and Ağllönü and Mengütay (2009) in "activities" subscale (3 items). Other than these, items that were developed by the researcher in line with the expert recommendations were also added (10 items).

\subsection{Data Analysis}

The analysis of the data was conducted in SPSS package program. As a result of normality test (Shapiro-Wilk), it was determined that the data didn't show normal distribution, so Mann Whitney U test was used for paired comparisons and Kruskall Wallis Analysis test was used to make comparisons of three and more groups. 


\section{Results}

Table 1. Mann Whitney-U test results regarding the subscales of preference factors in recreation area scale according to gender variable

\begin{tabular}{|c|c|c|c|c|c|c|}
\hline Subscales & Gender & $\mathbf{N}$ & Mean & Sd & $\mathbf{T}$ & $\mathbf{P}$ \\
\hline \multirow{2}{*}{ Sports Variety } & Male & 182 & 11.91 & 2.54 & \multirow{2}{*}{4.78} & \multirow{2}{*}{$.000 *$} \\
\hline & Female & 127 & 13.20 & 1.97 & & \\
\hline \multirow{2}{*}{ Personnel } & Male & 182 & 11.82 & 3.40 & \multirow{2}{*}{5.30} & \multirow{2}{*}{$.000 *$} \\
\hline & Female & 127 & 13.78 & 2.85 & & \\
\hline \multirow{2}{*}{ Location } & Male & 182 & 12.08 & 2.12 & \multirow{2}{*}{3.72} & \multirow{2}{*}{$.000 *$} \\
\hline & Female & 127 & 12.91 & 1.55 & & \\
\hline \multirow{2}{*}{ Physical Environment/Facilities } & Male & 182 & 36.16 & 6.13 & \multirow{2}{*}{4.17} & \multirow{2}{*}{$.000 *$} \\
\hline & Female & 127 & 38.83 & 4.47 & & \\
\hline \multirow{2}{*}{ Activities } & Male & 182 & 18.90 & 3.99 & \multirow{2}{*}{4.45} & \multirow{2}{*}{$.000 *$} \\
\hline & Female & 127 & 20.77 & 3.06 & & \\
\hline
\end{tabular}

As Table 1 demonstrates, Mann Whitney-U test was performed to determine whether the subscale scores of Preference Factors in Recreation Area Scale showed a significant difference according to gender variable. As a result of the analysis, a statistically significant difference was found in all of the subscales of Preference Factors in Recreation Area according to gender variable, and considering the mean scores this difference was found to be in favour of women. 


\section{Macrothink}

Journal of Educational Issues

ISSN 2377-2263 2020, Vol. 6, No. 1

Table 2. Mann Whitney-U test results regarding the subscales of preference factors in recreation area scale according to city variable

\begin{tabular}{|c|c|c|c|c|c|c|}
\hline Subscales & City & $\mathbf{N}$ & Mean & Sd & $\mathbf{T}$ & $\mathbf{P}$ \\
\hline \multirow{2}{*}{ Sports Variety } & Istanbul & 44 & 12.55 & 2.87 & \multirow{2}{*}{.31} & \multirow{2}{*}{.754} \\
\hline & Other & 265 & 12.42 & 2.32 & & \\
\hline \multirow{2}{*}{ Personnel } & Istanbul & 44 & 13.36 & 3.37 & \multirow{2}{*}{1.58} & \multirow{2}{*}{.113} \\
\hline & Other & 265 & 12.51 & 3.31 & & \\
\hline \multirow{2}{*}{ Location } & Istanbul & 44 & 12.74 & 1.81 & \multirow{2}{*}{1.16} & \multirow{2}{*}{.247} \\
\hline & Other & 265 & 12.37 & 1.96 & & \\
\hline \multirow{2}{*}{ Physical Environment/Facilities } & Istanbul & 44 & 36.64 & 4.76 & \multirow{2}{*}{.78} & \multirow{2}{*}{.432} \\
\hline & Other & 265 & 37.36 & 5.79 & & \\
\hline \multirow{2}{*}{ Activities } & Istanbul & 44 & 18.05 & 4.29 & \multirow{2}{*}{3.13} & \multirow{2}{*}{$.002 *$} \\
\hline & Other & 265 & 19.94 & 3.59 & & \\
\hline
\end{tabular}

As can be seen in Table 2, Mann Whitney-U test was performed to determine whether the subscale scores of Preference Factors in Recreation Area Scale showed a significant difference according to city variable, and statistically significant difference was found in activities subscale, and the mean scores revealed that this difference was in favour of other cities. 
Table 3. Mann Whitney-U test results regarding the subscales of preference factors in recreation area scale according to marital status variable

\begin{tabular}{|c|c|c|c|c|c|c|}
\hline Subscales & Marital Status & $\mathbf{N}$ & Mean & Sd & $\mathbf{T}$ & $\mathbf{P}$ \\
\hline \multirow{2}{*}{ Sports Variety } & Married & 14 & 12.29 & 2.75 & \multirow{2}{*}{.24} & \multirow{2}{*}{.806} \\
\hline & Single & 295 & 12.45 & 2.39 & & \\
\hline \multirow{2}{*}{ Personnel } & Married & 14 & 12.71 & 2.94 & \multirow{2}{*}{.09} & \multirow{2}{*}{.921} \\
\hline & Single & 295 & 12.62 & 3.34 & & \\
\hline \multirow{2}{*}{ Location } & Married & 14 & 10.93 & 3.05 & \multirow{2}{*}{2.98} & \multirow{2}{*}{$.003 *$} \\
\hline & Single & 295 & 12.50 & 1.85 & & \\
\hline \multirow{2}{*}{ Physical Environment/Facilities } & Married & 14 & 36.36 & 6.69 & \multirow{2}{*}{.61} & \multirow{2}{*}{.543} \\
\hline & Single & 295 & 37.30 & 5.61 & & \\
\hline \multirow{2}{*}{ Activities } & Married & 14 & 18.86 & 3.15 & \multirow{2}{*}{.82} & \multirow{2}{*}{.410} \\
\hline & Single & 295 & 19.71 & 3.78 & & \\
\hline
\end{tabular}

Table 3 indicates that Mann Whitney-U test was performed to determine whether the subscale scores of Preference Factors in Recreation Area Scale showed a significant difference according to marital status variable, and statistically significant differences were found in location subscale scores of single participants.

Table 4. Mann Whitney-U test results regarding the subscales of preference factors in recreation area scale according to private car variable

\begin{tabular}{|c|c|c|c|c|c|c|}
\hline Subscales & Private Car & $\mathbf{N}$ & Mean & Sd & $\mathbf{T}$ & $\mathbf{P}$ \\
\hline \multirow{2}{*}{ Sports Variety } & Yes & 51 & 11.73 & 2.91 & \multirow{2}{*}{2.33} & \multirow{2}{*}{$.020 *$} \\
\hline & No & 258 & 12.58 & 2.27 & & \\
\hline \multirow{2}{*}{ Personnel } & Yes & 51 & 12.65 & 3.07 & \multirow{2}{*}{.04} & \multirow{2}{*}{.962} \\
\hline & No & 258 & 12.62 & 3.38 & & \\
\hline \multirow{2}{*}{ Location } & Yes & 51 & 11.82 & 2.39 & \multirow{2}{*}{2.43} & \multirow{2}{*}{$.015 *$} \\
\hline & No & 258 & 12.55 & 1.82 & & \\
\hline \multirow{2}{*}{ Physical Environment/Facilities } & Yes & 51 & 35.67 & 6.47 & \multirow{2}{*}{2.21} & \multirow{2}{*}{.053} \\
\hline & No & 258 & 37.57 & 5.44 & & \\
\hline \multirow{2}{*}{ Activities } & Yes & 51 & 18.20 & 4.09 & \multirow{2}{*}{3.10} & \multirow{2}{*}{$.002 *$} \\
\hline & No & 258 & 19.96 & 3.62 & & \\
\hline
\end{tabular}




\section{Macrothink}

Journal of Educational Issues

ISSN 2377-2263 2020, Vol. 6, No. 1

As is seen in Table 4, Mann Whitney-U test was conducted to determine whether the subscale scores of Preference Factors in Recreation Area Scale showed a significant difference according to having a private car. As a result of the analysis, statistically significant difference was found between Preference Factors in Recreation Area Scale and private car variable in sports variety, location and activities subscales. According to the means, this difference was no found.

Table 5. Kruskall Wallis test results regarding the subscales of preference factors in recreation area scale according to age variable

\begin{tabular}{|c|c|c|c|c|c|c|c|}
\hline \multicolumn{2}{|l|}{ Subscales } & $\begin{array}{l}\text { Sum of } \\
\text { Squares }\end{array}$ & sd & $\begin{array}{l}\text { Mean of } \\
\text { Squares }\end{array}$ & $\mathbf{F}$ & $\mathbf{P}$ & Difference \\
\hline \multirow{3}{*}{ Sports Variety } & Intergroup & 12,766 & 2 & \multirow{3}{*}{$\begin{array}{l}6.383 \\
5.782\end{array}$} & \multirow{3}{*}{1.10} & \multirow{3}{*}{.333} & \multirow{3}{*}{ No } \\
\hline & Intragroup & 1769,376 & 306 & & & & \\
\hline & Total & 1782,142 & 308 & & & & \\
\hline \multirow{3}{*}{ Personnel } & Intergroup & 37,205 & 2 & \multirow{3}{*}{$\begin{array}{l}18.603 \\
11.023\end{array}$} & \multirow{3}{*}{1.68} & \multirow{3}{*}{.187} & \multirow{3}{*}{ No } \\
\hline & Intragroup & 3372,996 & 306 & & & & \\
\hline & Total & 3410,201 & 308 & & & & \\
\hline \multirow{3}{*}{ Location } & Intergroup & 7,138 & 2 & \multirow{3}{*}{$\begin{array}{l}3.569 \\
3.800\end{array}$} & \multirow{3}{*}{.93} & \multirow{3}{*}{.392} & \multirow{3}{*}{ No } \\
\hline & Intragroup & 1132,430 & 306 & & & & \\
\hline & Total & 1139,568 & 308 & & & & \\
\hline \multirow{3}{*}{ Physical Environment/Facilities } & Intergroup & 171,008 & 2 & \multirow{3}{*}{$\begin{array}{l}85.504 \\
31.674\end{array}$} & \multirow{3}{*}{2.69} & \multirow{3}{*}{.069} & \multirow{3}{*}{ No } \\
\hline & Intragroup & 9692,280 & 306 & & & & \\
\hline & Total & 9863,288 & 308 & & & & \\
\hline \multirow{3}{*}{ Activities } & Intergroup & 148,154 & 2 & \multirow{3}{*}{$\begin{array}{l}74.077 \\
13.708\end{array}$} & \multirow{3}{*}{5.40} & \multirow{3}{*}{$.005 *$} & \multirow{3}{*}{$\begin{array}{l}1-2 \\
1-3\end{array}$} \\
\hline & Intragroup & 4194,512 & 306 & & & & \\
\hline & Total & 4342,667 & 308 & & & & \\
\hline
\end{tabular}

As shown in Table 5, Kruskall Wallis test was used to determine whether the subscale scores of Recreational Area Preference Factors Scale showed a significant difference according to age variable, and a statistically significant difference was found in activities subscale. 


\section{Ml Macrothink}

Tablo 6. Kruskall Wallis test results regarding the subscales of preference factors in recreation area scale according to department variable

\begin{tabular}{|c|c|c|c|c|c|c|c|}
\hline \multicolumn{2}{|l|}{ Subscales } & $\begin{array}{l}\text { Sum of } \\
\text { Squares }\end{array}$ & SD & $\begin{array}{l}\text { Mean of } \\
\text { Squares }\end{array}$ & $\mathbf{F}$ & $\mathbf{P}$ & Difference \\
\hline \multirow{3}{*}{ Sports Variety } & Intergroup & 18,185 & 3 & \multirow{3}{*}{$\begin{array}{l}6.062 \\
5.783\end{array}$} & \multirow{3}{*}{1.04} & \multirow{3}{*}{.372} & \multirow{3}{*}{ No } \\
\hline & Intragroup & 1763,957 & 305 & & & & \\
\hline & Total & 1782,142 & 308 & & & & \\
\hline \multirow{3}{*}{ Personnel } & Intergroup & 204,708 & 3 & \multirow{3}{*}{$\begin{array}{l}68.236 \\
10.510\end{array}$} & \multirow{3}{*}{6.49} & \multirow{3}{*}{$.000 *$} & \multirow{3}{*}{$1-2$} \\
\hline & Intragroup & 3205,493 & 305 & & & & \\
\hline & Total & 3410,201 & 308 & & & & \\
\hline \multirow{3}{*}{ Location } & Intergroup & 21,792 & 3 & \multirow{3}{*}{$\begin{array}{l}7.264 \\
3.764\end{array}$} & \multirow{3}{*}{1.93} & \multirow{3}{*}{.125} & \multirow{3}{*}{ Yok } \\
\hline & Intragroup & 1117,776 & 305 & & & & \\
\hline & Total & 1139,568 & 308 & & & & \\
\hline \multirow{3}{*}{ Physical Environment/Facilities } & Intergroup & 92,890 & 3 & \multirow{3}{*}{$\begin{array}{l}30.963 \\
32.034\end{array}$} & \multirow{3}{*}{.96} & \multirow{3}{*}{.409} & \multirow{3}{*}{ Yok } \\
\hline & Intragroup & 9770,398 & 305 & & & & \\
\hline & Total & 9863,288 & 308 & & & & \\
\hline \multirow{3}{*}{ Activities } & Intergroup & 22,613 & 3 & \multirow{3}{*}{$\begin{array}{l}7.538 \\
14.164\end{array}$} & \multirow{3}{*}{.532} & \multirow{3}{*}{.661} & \multirow{3}{*}{ Yok } \\
\hline & Intragroup & 4320,053 & 305 & & & & \\
\hline & Total & 4342,667 & 308 & & & & \\
\hline
\end{tabular}

Table 6 displays that Kruskall Wallis test was used to determine whether the subscale scores of Recreational Area Preference Factors Scale showed a significant difference according to department variable, and a statistically significant difference was found in personnel subscale.

\section{Conclusion}

The studies on recreation areas in our country are important for the use of these areas by more people and in accordance with their purpose. Investigating the factors that are effective on public to use recreation areas more intensively and purposefully will make significant contributions to our country in terms of recreation services, and such investigations will act as a resource to guide local governments in the planning of such areas or modernization of the existent areas (Gümüş, 2017). According to the literature is analyzed, most of the studies performed on the preference of recreation and parking areas in the urban and rurals (Boll et al., 2014; Winter \& Lackwood, 2005; Ezebilo et al., 2013), but there is not much researches on the factors effecting these preference. Consequently this study aimed to determine the factors effecting university students' preferences of recreation areas. 
In the study, a statistically significant difference was found in all of the subscale scores of Recreation Area Preference Factors according to gender variable and this difference was found to be in favour of women when the mean scores were examined. The reason for this difference can be because of some situations like women's not feeling safe. When we look at the literature (Gürbüz \& Henderson, 2014), women reported that they face more obstacles than men in terms of participation in recreation.

There was a statistically significant difference in activity subscale of Recreation Area Preference Factors according to location variable and this difference was found to be in favour of other cities when the average scores were examined. It is seen that the students living outside of Istanbul face more obstacles in the subscale of participation in activities according to the city of residence variable.

As a result of the analysis conducted regarding the marital status variable, a statistically significant difference was found in location subscale scores of the single participants. This indicates that the location of recreation areas is more important for single participants. The result of the analysis regarding age variable revealed that a statistically significant difference was found in activities subscale. In the study of Doğan (2016), a significant difference was found according to age and marital status variables and the results show parallelism with our study.

It was seen that having a private car was effective in students' preference for recreational activities individually or for sports areas in sports variety, location and activities subscales. As a result of the analysis performed according to department variable, a statistically significant difference was found in personnel subscale. In other words, the presence of the sports trainer and someone as a consultant in the field of recreation is a factor in the preference of participation in recreation.

Godbey listed the major factors that affect recreational activities as proximity, security, support and design of recreational areas. In addition, he claimed that the other factors affecting participation in recreational activities include individual's having free time and the society's perspective (Godbey, 2009). Research studies have revealed that recreation and leisure services are essential as they can improve people's life quality. Therefore, considering the effects of participation in recreation that protects or increases life quality of the society, providing recreational services should be the primary responsibility of local governments (Baker \& Palmer, 2006).

It should be intended that more individuals use recreation areas to be built by local governments in order to create a healthy citizen and a healthy city. This research provided some insights into understanding how leisure activity preferences, the attitudes and experiences of university students. More studies are needed on general populations in countries, but as an exploratory study, these student responses provided some understanding of investigate the preference factors of university students studying in sports sciences faculty and living in different areas for the use of recreational areas built by municipalities. In order to attract more individuals to recreation areas, it is quite essential to know the factors that affect the users to prefer recreation areas and to plan new recreation areas or to modernize the 
old ones in the light of this information (Doğan \& Gümüş, 2016).

\section{References}

Ağılönü, A., \& Mengütay, S. (2009). Recreation services and model determination in local governments. International Journal of Human Sciences, 6(2), 292-301.

Baker, D. A., \& Palmer, R. J. (2006). Examining the effects of perceptions of community and recreation participation on quality of life. Social Indicators Research, 75(3), 395-418. https://doi.org/10.1007/s11205-004-5298-1

Boll, T., von Haaren, C., \& von Ruschkowski, E. (2014). The Preference and Actual Use of Different Types of Rural Recreation Areas by Urban Dwellers-The Hamburg Case Study. PLOS ONE, 9(10), e108638. https://doi.org/10.1371/journal.pone.0108638

Boman, M.-F., Lundmark, P., \& Ericsson, L. (2013). Outdoor recreation-A necessity or a luxury? Estimation of engel curves for Sweden. Journal of Outdoor Recreation and Tourism, 3(4), 49-56. https://doi.org/10.1016/j.jort.2013.09.002

Demirel, M., \& Harmandar, D. (2009). Determination of the constraints on recreational participation of university students. International Journal of Human Sciences, 1, 6.

Doğan, İ., \& Gümüş, H, (2016). Recreation area preference and body mass index relationship. The 2nd International Conference on the Changing World and Social Research (ICWSR'2016) October, 14-16, 2016, Barcelona-Spain.

Ezebilo, E. E., Boman, M., Mattsson, L., Lindhagen, A., \& Mbongo, W. (2015). Preferences and willingness to pay for close to home nature for outdoor recreation in Sweden, Journal of Environmental Planning and Management, 58(2), 283-296. https://doi.org/10.1080/09640568. 2013.854196

Godbey, G. (2009). Outdoor Recreation, Health, and Wellness: Understanding and Enhancing the Relationship. RFF Discussion Paper No. 09-21. https://doi.org/10.2139/ssrn. 1408694

Gümüş, H., \& Alay Özgül, S. (2017). Developing the scales of participation barriers and preference factors related to recreation use. Journal of Human Sciences, 14(1), 865-882. https://doi.org/10.14687/jhs.v14i1.4448

Gürbüz, B., \& Henderson, K. A. (2014). Leisure activity preferences and constraints: Perspectives from Turkey. Word Leisure Journal, 56(4), 300-316. https://doi.org/10.1080/ 16078055.2014.958195

Karaküçük, S. (1995). Recreation. Seren Publisher, Ankara.

Karaküçük, S. (2005). Recreation (Leisure). Gazi Publisher, Ankara.

Öcal, K. (2012). Scale development: Free time physical activity constraints (SZFA-K). Journal of Sports Sciences, 23(2), 50-60.

Pelletier, L. G., Fortier, M. S., Vallerand, R. J., Tuson, K. M., Briere, N. M., \& Blais, M. R. 
(1995). Toward a new measure of intrinsic motivation, extrinsic motivation, and amotivation in sports: The Sport Motivation Scale (SMS). Journal of sport and Exercise Psychology, 17, 35-35. https://doi.org/10.1123/jsep.17.1.35

Stanis, S. A. W., Schneider, I. E., Chavez, D. J., \& Shinew, K. J. (2009). Visitor constraints to physical activity in park and recreation areas: Differences by race and ethnicity. Journal of Park and Recreation Administration, 27(3), 78-95.

Tuncay, S. (2000). Psychological Aspects of Youth Issues in Turkey. Journal of Muğla University Institute of Social Sciences, 1(1), 244-251.

Tütüncü, Ö., Aydın, İ., Küçükusta, D., Avcı, N., \& Taş, İ. (2011). Analysis of factors affecting university students' participation in recreation activities. Journal of Sports Sciences, 22(2), 69-83.

Uzun, S., \& Muderrisoğlu, H. (2010). User satisfaction in rural recreation areas: Bolu lagoon example of resting place in the forest. Suleyman Demirel University Faculty of Forestry Journal, A(1), 67-82.

Voight, D. (1998). Sport Sociology. Ankara, Turkey.

Wilcox, S., Castro, C., King, A. C., Housemann, R., \& Brownson, R. C. (2000). Determinants of leisure time physical activity in rural compared with urban older and ethnically diverse women in the United States. Journal of Epidemiology Community Health, 54, 667-673. https://doi.org/10.1136/jech.54.9.667

Winter, C., \& Lockwood, M. (2005). A model for measuring natural area values and park preferences. Environmental Conservation, 32(3), 270-278. https://doi.org/10.1017/S0376892 90500246

Yetim, A. (2011). Sociology and Sport. Berikan Publisher, Ankara.

\section{Copyright Disclaimer}

Copyright for this article is retained by the author(s), with first publication rights granted to the journal.

This is an open-access article distributed under the terms and conditions of the Creative Commons Attribution license (http://creativecommons.org/licenses/by/3.0/). 